\title{
Validation of a Classroom Management Questionnaire for pre and Inservice Teachers of English
}

Validación de un cuestionario de manejo del aula para profesores de inglés en formación y practicantes

Validação de um questionário de gestão da sala de aula para professores de inglês em formação e em exercício

Claudio Díaz* iD orcid.org/0000-0002-9024-2497

Georgina González** iD orcid.org/0000-0002-6574-3687

Lucas Ignacio Jara-Ramírez *** (iD) orcid.org/0000-0001-6614-4435

Javiera Alejandra Muñoz-Parra**** (iD orcid.org/0000-0002-0096-8981

\begin{abstract}
Artículo de investigación
Revista Colombiana de Educación, N.7 75. Segundo semestre de 2018, Bogotá, Colombia.

doi: 10.17227/rce.num75-8111

Para citar este artículo: Díaz, C., González, G., Jara-Ramírez, L. y Muñoz-Parra, J. (2018). Validation of a Classroom Management Questionnaire for pre and Inservice Teachers of English. Revista Colombiana de Educación, 75, 263-285.
\end{abstract}

\section{(c) $\underset{\mathrm{BY}}{\mathrm{B} \mathrm{NC}}$}

* Doctor en Educación y magister en Lingüística. Director Magíster en Innovación de la Enseñanza, Aprendizaje y Evaluación del Inglés, Universidad de Concepción, Chile. Correo electrónico: claudiodiaz@udec.cl

** Licenciada en Educación y profesora de inglés Universidad de Concepción, Chile. Correo electrónico: geogonzalez@udec.cl

*** Licenciado en Educación y profesor de inglés Universidad de Concepción, Chile. Correo electrónico: Iucajara@udec.cl

**** Licenciada en Educación y profesora de inglés, Universidad de Concepción, Chile. Correo electrónico: javieramunoz@udec.cl 


\begin{abstract}
Classroom management is a permanent concern and challenge for teachers. Good classroom management practices are critical to facilitate effective learning and therefore, researchers are continuously exploring ways to measure this construct from different perspectives. Questionnaires are one of the tools used to gather relevant data. This article presents an approach to the validation of a classroom management questionnaire. To validate this questionnaire, items were assessed by experts in the field through the application of two member checking techniques, namely, Delphi and Fleiss' Kappa that implied a series of changes in some of the items. Finally, a small pilot testing conducted among pre and in-service teachers of English yielded an excellent Cronbach's Alpha, resulting in a highly reliable questionnaire.
\end{abstract}

\section{Keywords}

classroom management; questionnaires; Delphi; Fleiss' Kappa; Cronbach's Alpha

\section{Palabras clave}

manejo del aula; cuestionarios Delphi; Fleiss' Kappa; Cronbach's Alpha

\section{Resumen}

El manejo del aula es una preocupación permanente y un desafío para los maestros. Las buenas prácticas de manejo del aula son fundamentales para facilitar el aprendizaje efectivo y, por lo tanto, los investigadores continuamente exploran formas de medir esta construcción desde diferentes perspectivas. Los cuestionarios son una de las herramientas utilizadas para recopilar datos relevantes. Este artículo presenta un enfoque para la validación de un cuestionario de manejo del clase. Para validar este cuestionario, los elementos fueron evaluados por expertos en el campo a través de la aplicación de técnicas de verificación de dos miembros, a saber Delphi y Kappa de Fleiss, lo que implicó una serie de cambios en algunos de los artículos. Finalmente, una pequeña prueba piloto que se llevó a cabo entre maestros de inglés en formación y practicantes dio como resultado un excelente Alfa de Cronbach, lo que resultó en un cuestionario altamente confiable.

\title{
Resumo
}

A gestão da sala de aula é uma preocupação constante e um desafio para os professores. As boas práticas de gestão da sala de aula são vitais para facilitar a aprendizagem efetiva, é por isso que os pesquisadores exploram constantemente formas de medir este constructo desde diversas perspectivas. Os questionários são algumas das ferramentas utilizadas para obter dados relevantes. Este artigo apresenta uma abordagem da validação de um questionário de gestão da sala de aula. Para validar o questionário, os itens foram avaliados por expertos no campo através da aplicação de técnicas chamadas Delphi e Fleiss' Kappa, que implicaram uma série de mudanças em alguns itens. Finalmente, um piloto de prova levado a cabo entre professores em formação e em exercício obteve um excelente Alpha de Cronbach, o que o constitui como um questionário altamente confiável.

\section{Palavras-chave}

gestão da sala de aula questionários; Delphi; Fleiss' Kappa; Alpha de Cronbach 


\section{Introduction}

Classroom management is a matter of concern among teachers everywhere. In fact, Gordon (as cited in Okutan, 2005), indicates that managing a classroom can be a critical challenge, especially for beginner teachers, but even for experienced ones. Being the first professional activity to be developed, classroom management is assumed as part of teachers' duties and one of their main responsibilities (Marzano, 2003).

Hence, it is of high relevance for both teachers and other stakeholders to identify the classroom management techniques that teachers use or are more likely to be used. This can be helpful for a number of reasons: 1) to be aware of the techniques teachers mostly tend to use; 2 ) to identify patterns of behavior; 3 ) to find out which ones are more effective; 4) to identify teachers' beliefs behind their actions inside and outside the classroom; and, one of the most relevant ones, 5) to enable pedagogical reflection by making teachers aware of their teaching process in order to identify weaknesses and strengths, as well as possible modifications of their practices. In fact, Martin, Schafer, McClowry, Emmer, Brekelmans, Mainhard, and Wubbels (2016) concluded that classroom management is a powerful component of the overall classroom climate that affects students' behavior, engagement, and, by extension, the quality of students' learning.

One of the main tools that contribute to the effective investigation of classroom management is questionnaires. Researchers use them widely and frequently to collect relevant data with the purpose of reaching and supporting their findings. It is important then, to count on reliable and valid questionnaires, which reflect on current views about classroom management. While examining old and new instruments utilized for different types of research on classroom management practices and teachers' beliefs behind those practices, it was uncovered that, even though there exists an array of them, one of their weaknesses is they are outdated. For example, most of the instruments do not include current topics like social networks, parental involvement, or new findings and understandings of the topic. Indeed, a number of questionnaires that do include recent views on classroom management are addressed specifically to teachers who teach kids, not to English teachers in general. Therefore, there are no recent instruments that deal with classroom management techniques used specifically by English teachers, making the creation of a questionnaire on this area paramount.

This study aims at approaching the validation of a CMQ using two member-checking techniques (Delphi and Fleiss' Kappa) and at estimating the CMQ internal consistency, using Cronbach's alpha. This paper is part of the Fondecyt 1150889 research grant, "Las dimensiones cognitivas, 
afectivas y sociales del proceso de planificación de aula y su relación con los desempeños pedagógicos en estudiantes de práctica profesional y profesores nóveles de pedagogía en inglés."

\section{Theoretical Framework}

The concept of classroom management has been widely defined, and every author explains it from a different perspective. According to Özcan (2017), "classroom management is an ongoing interaction between teachers and their students" (p. 111). Consequently, the concept can be understood as all the actions performed by the teacher to create and maintain a learning environment that enables successful instruction. This includes a variety of techniques, like arranging the physical environment, establishing rules and procedures, maintaining students' attention to lessons, and engagement in activities (Özcan, 2017).

Classroom management has also been defined as the actions teachers take to create a supportive environment for the academic and social emotional learning of students (Özcan, 2017). Therefore, classroom management can be seen as all the actions that a teacher performs inside a school in order to enable learning. Classroom management can be thus conceived as all the educational decisions teachers make (Marzano, Marzano, \& Pickering, 2003).

\section{Historical Review of Classroom Management Questionnaires}

The first attempt to measure classroom management practices was made by Willower, Eidell, and Hoy (1967) with the Pupil Control Ideology (PCI) scale. The PCI form, as described by Hoy (2001), is a 20-item Likert-type scale with 5 response categories for each item ranging from "strongly agree" to "strongly disagree." This inventory is based on an ideological continuum going from custodial (more controlling; teacher does not attempt to understand student's misbehavior) to humanistic (less controlling; teacher believes student can learn to be a self-regulating individual).

Later on, Wolfgang and Glickman (1986) conceived another framework to explain teachers' beliefs toward classroom management. This framework was the basis for the Beliefs on Discipline Inventory (BDI). It consists of three parts: prediction items (3 questions), forced choice items (12 questions) and self-scoring and interpretation (3 steps). This last part includes comparing results of the forced choice part with the predictions made in part 1 . Similarly to the PCI form, it is based on a teacher-student control continuum, which illustrates three approaches to classroom 
interaction: non-interventionists (low teacher control-high student control), interventionists (high teacher control-low student control), and interactionalists (equal teacher control-equal student control).

In 1993, Nancy Martin and Beatrice Baldwin presented a new questionnaire based on both of the premises previously described, the Pupil Control Ideology form and Beliefs on Discipline Inventory. It was called the Inventory of Classroom Management Style (ICMS). It used the same BDI's continuum from a most non-interventionist approach to a most interventionist approach with a mid-point (interactionalist approach).

The ICMs has 48 Likert-type items and the idea of its format was taken from the $\mathrm{PCl}$ questionnaire, but with different descriptors. The novelty of this instrument, unlike its predecessors, was the holistic point of view regarding classroom management, grouping items into three dimensions: person, instruction and discipline. The focus was removed from discipline, considering classroom management as "a multi-faceted construct [...] a broad, umbrella term that includes, but is not limited to, discipline concerns" (Martin \& Baldwin, 1993, p. 4).

Then, one year later, Nault (1994) created an inventory called Questionnaire on Classroom Management in Early Childhood Education (QCME) addressed specifically to teachers who teach young children. It is formed by 100 items distributed unequally within four dimensions related to planning, organization, intervention, and evaluation.

More than a decade later, Pearson Education Canada Inc. (2005) launched an updated version of Beliefs on Discipline Inventory with a quite similar name: Beliefs about Discipline Inventory. This questionnaire does not present the three parts that its predecessor (BDI) had, but only one section that resembles part 2 of the earlier version of the inventory, keeping just the part of forced choices, rewording the same 12 statements with dichotomous answer (a or b).

More modern inventories include the one developed by Webster-Stratton (2012) to assess teachers' performance when applying a training program with young children. The Teacher Classroom Management Strategies Questionnaire has four sections with different scales for each one. It has very specific and comprehensive items intended to find out the usefulness and frequency of use of a variety of classroom management techniques, supposedly applied by teachers who are taking the course, especially those related to discipline, work with parents and planning. The most recent instrument found is the one developed by Awad (2016); it is a simple 14-item questionnaire to measure teachers' views on their classroom management competencies and their views on the quality of their pre-service training and the in-service support from their schools with a Likert-type scale. 


\section{Appraisal of Classroom Management Instruments}

One of the weaknesses detected in some of the inventories analyzed is the language used to formulate the items. Let us take the case of the PCI form. There are just 2 out of the 20 items, which convey a positive sense when reading it. The remaining 18 items convey a quite negative message when referring to student misbehavior, persistently highlighting discipline and order, which obviously would not depict current views on classroom management. It may be evident enough for teachers what responses are expected from them, even though the questionnaire is anonymous, which may lead to unreliable answers.

Like the $\mathrm{PCl}$ form, the $\mathrm{BDI}$ is highly focused on disciplinary aspects without taking into account that interaction with students implies a lot more than just that area. Noteworthy is the inventory's layout, especially part 2, where dichotomous statements force teachers to decide between two extreme views, leaving no room for intermediate positions. Another flaw is the absence of categories or dimensions. In some instruments there is not a guiding or logical thread within items. Meanwhile, inventories that do include these aspects do not have items organized into categories or dimensions, resulting in mixed questions, which seem disconnected, as loose statements referring almost entirely to discipline aspects, leaving aside other important areas of classroom management. This is especially true in the case of instruments with few questions. Some of the modern instruments described, which make a contribution adding more characteristics than just the discipline area, suffer from being either too long, as it is the case of Nault's (1994) QCME inventory with 100 items, or too short, the most recent questionnaire found developed by Awad (2016) with just 14 items.

Life at school involves a variety of aspects. Classroom management, as has already been said, involves almost all teachers' actions. Taking into account the historical background reviewed, it has been made evident the need of a new instrument that better depicts our times and the current understanding of the classroom management construct.

\section{Methodology}

\section{Research Design}

This is a non-experimental and descriptive study. It is also cross-sectional, because the data was collected in one specific period of time. 


\section{Research Objectives}

» To validate the CMQ using two member checking techniques (Delphi and Fleiss' Kappa).

» To estimate the CMQ internal consistency using Cronbach's alpha.

\section{Research Participants}

An early version of the Classroom Management Questionnaire was given to a review board of language experts, to be rated in order to evaluate its validity. The review board was formed by 12 experts in the field. Of the 12 expert participants, 8 were women, representing $67 \%$ of the total.

The Classroom Management Questionnaire was applied to 31 English teachers, $81 \%$ of whom were between the ages of 21 and 30 years old. Out of the 31 participants, 24 were women, representing $77 \%$ of the total. Additionally, most of the participants who answered the CMQ taught in secondary public school education with a few participants working in two different school levels.

\section{Instrument}

The questionnaire had a Likert-type modality going from "Rarely" to "Usually," and 60 items were distributed equally within three main dimensions: discipline, teaching and learning, and personal. Each dimension was made up of 20 items. The items were mainly adapted from different sources: questionnaires addressed to teachers who teach young learners and classroom management books. Below are the four sources used in the design of the CMQ:

»Questionnaire on Classroom Management in Early Childhood Education (QCME) (Nault, 1994)

» Teacher Classroom Management Strategies Questionnaire (Webster-Stratton, 2012)

» A Handbook for Classroom Management that Works (Marzano, Foseid, Foseid, Gaddy, \& Marzano, 2005)

»Classroom Management Techniques (Scrivener, 2012)

Some of the items, which were exclusively applicable to young learners, were adapted and reworded to make them more general. Likewise, some items were created on the basis of the introduction of new technologies into the classroom, such as the Internet and social networks. 


\section{Type of Statistical Analysis}

Validity and reliability are two fundamental elements in the validation of a questionnaire. Validity is the extent to which an instrument measures what it is intended to measure. Reliability is intended to test the overall consistency of an instrument (Tavakol \& Dennick, 2011). For this study three statistical techniques were used and are briefly described below.

\section{Delphi Technique}

The Delphi technique is a widely used and accepted method for gathering data from respondents within their domain of expertise. Basically, consensus on a topic can be reached if a certain percentage of the votes fall within a specific range. The use of mean scores, based on a Likert-type scale, is strongly favored. The mean appears to be inherently best suited to reflect the resultant convergence of opinion. It has been suggested that the mean has to be at 3.25 or higher to reach a consensus on a certain topic (Hsu \& Sandford, 2007).

\section{Fleiss' Kappa Technique}

Fleiss' Kappa evaluates the concordance or agreement between multiple raters. It is a measure of the degree of agreement that can be expected above chance. Agreement can be thought of as follows: If a fixed number of people assign numerical ratings to a number of items, then the Kappa will give a measure for how consistent the ratings are. Table 1 describes the benchmark scale that Landis and Koch (1977) proposed, one of the most widely used benchmark scales to value the degree of agreement between raters in function of Kappa.

Table 1. Landis and Koch Kappa's Benchmark Scale

\begin{tabular}{c|c} 
Kappa & Interpretation \\
$<0$ & Poor agreement \\
$0.01-0.20$ & Slight agreement \\
$0.21-0.40$ & Fair agreement \\
$0.41-0.60$ & Moderate agreement \\
$0.61-0.80$ & Substantial agreement \\
$0.81-1.00$ & Almost perfect agreement
\end{tabular}

Source: Landis and Koch (1977, p. 165).

\section{Cronbach's Alpha}

This technique is a measure of internal consistency of tests or questionnaires in order to validate their reliability. It is commonly used in questionnaires with multiple Likert questions whose answers are neither correct nor incorrect, but each participant chooses the alternative that best depicts his 
or her own views on the construct intended to explore. Internal consistency refers to the extent to which a set of items in a questionnaire measures the same concept or construct that he or she intends to measure and, therefore, it is connected to the inter-relatedness of the items within the test. If the items in a questionnaire are correlated to each other, the alpha value is increased. These values range between 0 and 1 , in which 0 means "no reliability at all" and 1 means "total reliability." The closer the alpha value is to 1 , the higher the inventory's reliability. Table 2 represents the values proposed by George and Mallery (2003).

Table 2. George and Mallery's scale

\begin{tabular}{c|c}
\hline Alpha & Internal consistency \\
$\alpha \geq 0.9$ & Excellent \\
$0.9>\alpha \geq 0.8$ & Good \\
$0.8>\alpha>0.7$ & Acceptable \\
$0.7>\alpha>0.6$ & Questionable \\
$0.6>\alpha \geq 0.5$ & Poor \\
$0.5>\alpha$ & Unacceptable \\
\hline
\end{tabular}

Source: George and Mallery (2003, p. 231).

\section{Data Analysis and Discussion}

\section{Specific objective 1}

To validate the CMQ using two member checking techniques (Delphi and Fleiss' Kappa).

\section{Delphi Technique Applied to the CMQ}

The instrument was evaluated by a total of 12 language experts who rated the clarity, coherence, and relevance of each one of the statements from one to four points in a Likert-type scale. Each classification is understood as follows:

»Clarity. The item is easily understood, that is, its syntax and semantic are appropriate.

»Coherence. The item shows a logic relationship with the aim or indicator it is measuring.

"Relevance. The item is essential or important, that is, it has to be included in the instrument.

The statements were assessed by the raters under the following categories: 1) does not meet the criterion; 2) low level; 3) moderate level; and 4) high level, as shown in Table 3 below. 
Figure 3. Sample of rubric

\begin{tabular}{|c|c|c|c|c|c|c|c|c|c|c|c|c|}
\hline Item & \multicolumn{3}{|c|}{ Clarity } & \multicolumn{3}{|c|}{ Coherence } & \multicolumn{3}{|c|}{ Relevance } \\
\hline $\begin{array}{c}\text { 1. Involve students in establishing } \\
\text { rules and procedures. }\end{array}$ & 1 & 2 & 3 & 4 & 1 & 2 & 3 & 4 & 1 & 2 & 3 & 4 \\
\hline
\end{tabular}

Source: Own elaboration.

The instrument was separated into three dimensions-discipline, teaching and learning, and personal—in order to analyze it through the Delphi technique.

\section{Discipline dimension analysis}

As stated previously, the suggested mean for an item to be accepted as appropriate (clear, coherent, relevant) is 3.25 or higher. Therefore, every item was considered as appropriate by the specialized subjects, with the exception of items 15, 16, and 20. These three items measured under the suggested mean score had to be revised in order to fulfill the characteristics of a properly written item. Additionally, items 16 and 20 were relocated to enhance the coherence among items within this dimension in order to be logical as the participant was reading the questionnaire. Items that narrowly surpassed the suggested mean score were also rewritten, as in the case of item 6.

Table 4 shows the lowest mean score of the answers provided by the participants for the items belonging to the Discipline dimension.

Table 4. Lowest mean score items for the Discipline dimension

\begin{tabular}{|c|l|c|c|c|}
\hline$\#$ & \multicolumn{1}{c|}{ Item } & $\begin{array}{c}\text { Clarity mean } \\
\text { score }\end{array}$ & $\begin{array}{c}\text { Coherence } \\
\text { mean score }\end{array}$ & $\begin{array}{c}\text { Relevance } \\
\text { mean score }\end{array}$ \\
\hline 6. & $\begin{array}{l}\text { Reprimand bad behavior on } \\
\text { the spot in a loud voice. }\end{array}$ & 3.58 & 3.27 & 3.27 \\
\hline $\begin{array}{l}\text { Send a student home for aggressive } \\
\text { or destructive behavior. }\end{array}$ & 3.63 & 3.18 & 3.18 \\
\hline 16. $\begin{array}{l}\text { Send a student to the Principal's } \\
\text { Office for misbehavior. }\end{array}$ & 3.9 & 3.45 & 3.18 \\
\hline 20. $\begin{array}{l}\text { Inform parents about how social } \\
\text { networks work and their correct use. }\end{array}$ & 3.9 & 3.45 & 3 \\
\hline
\end{tabular}

\section{Source: Own elaboration.}

The changes made followed the comments and suggestions given by the specialized raters. Most of them suggested writing the pronoun "I" before every item instead of having the pronoun in the introductory statement at the beginning of each dimension, as it was in the first version of the CMQ. Table 5 shows the changes made to the mentioned items and how the revised statement was rewritten. 
Table 5. Changes made to items 6, 15, 16, and 20

\begin{tabular}{|c|c|c|}
\hline Item & Original statement & Revised statement \\
\hline 6 & $\begin{array}{l}\text { Reprimand bad behavior on } \\
\text { the spot in a loud voice. }\end{array}$ & $\begin{array}{l}\text { I redirect inappropriate behavior } \\
\text { on the spot, using a loud voice. }\end{array}$ \\
\hline 15 & $\begin{array}{l}\text { Send a student home for aggressive } \\
\text { or destructive behavior. }\end{array}$ & $\begin{array}{l}\text { I send students home for aggressive } \\
\text { or disruptive behavior. }\end{array}$ \\
\hline 16 & $\begin{array}{l}\text { Send a student to Principal's } \\
\text { Office for misbehavior. }\end{array}$ & $\begin{array}{l}\text { I send students to the Principal's office } \\
\text { for misbehavior (relocated as Item 20). }\end{array}$ \\
\hline 20 & $\begin{array}{l}\text { Inform parents about how social } \\
\text { networks work and their correct use. }\end{array}$ & $\begin{array}{l}\text { I inform parents about social } \\
\text { networks and their correct use } \\
\text { (e.g., Facebook, Twitter, and } \\
\text { Instagram) (relocated as Item 17). }\end{array}$ \\
\hline
\end{tabular}

\section{Source: Own elaboration.}

\section{Teaching and Learning dimension analysis}

Table 6 shows the lowest mean score of the answers provided by the subjects for the items belonging to the Teaching and Learning dimension. In this case, specialized participants considered every item as appropriate, with the exception of item 39. The item, which was measured under the mean score suggested in terms of clarity, had to be revised in order to fulfill the characteristics of a properly written item. The changes made, following the comments and suggestions given by specialized participants, are shown in Table 7.

Table 6. Lowest mean score items for the Teaching and Learning dimension

\begin{tabular}{|c|l|c|c|c|}
\hline \# & \multicolumn{1}{|c|}{ Item } & $\begin{array}{c}\text { Clarity mean } \\
\text { score }\end{array}$ & $\begin{array}{c}\text { Coherence } \\
\text { mean score }\end{array}$ & $\begin{array}{c}\text { Relevance } \\
\text { mean score }\end{array}$ \\
\hline 39. $\begin{array}{l}\text { Offer students guidelines and } \\
\text { suggestions to report the group } \\
\text { about their completed work. }\end{array}$ & 2.75 & 3.54 & 3.54 \\
\hline
\end{tabular}

\section{Source: Own elaboration.}

Table 7. Changes made to item 39

\begin{tabular}{|c|c|c|}
\hline Item & Original statement & Revised statement \\
\hline 39. & $\begin{array}{l}\text { Offer students guidelines and } \\
\text { suggestions to report the group } \\
\text { about their completed work. }\end{array}$ & $\begin{array}{l}\text { I give students instructions on how } \\
\text { to report their completed work. }\end{array}$ \\
\hline
\end{tabular}

\section{Source: Own elaboration.}

\section{Personal dimension analysis}

In the case of the Personal dimension, the specialized participants considered every item as appropriate. Therefore, no changes were made to any of the items belonging to this section. 


\section{Fleiss' Kappa applied to the cMQ}

The instrument was evaluated by a total of 12 experts who rated the clarity, coherence, and relevance of each one of the statements from one to four points in a Likert-type scale. The statements were classified by the raters under the following categories: 1) does not meet the criterion; 2) low level; 3) moderate level; and 4) high level. The instrument was separated into three dimensions: Discipline, Teaching and Learning, and Personal in order to analyze it with the Fleiss's Kappa coefficient.

\section{Discipline dimension analysis}

Table 8 shows items with the lowest Fleiss' Kappa coefficient in the Discipline dimension. As stated above, a Kappa value between 0.41 and 0.60 indicates a moderate agreement level, while ranges of values $(0.61$ to $0.80)$ and (0.81 to 1.00) indicate substantial and almost perfect agreement levels respectively. Therefore, according to the Fleiss' Kappa Coefficient applied to the instrument, there is a moderate agreement, a substantial agreement or an almost perfect agreement among raters in every item, with the exception of items $6,15,16$, and 20, which were rated with a fair agreement among experts.

Table 8. Lowest Fleiss' Kappa coefficient for the Discipline dimension

\begin{tabular}{|l|l|c|c|c|}
\hline \# & \multicolumn{1}{c|}{ Item } & Clarity Kappa & $\begin{array}{c}\text { Coherence } \\
\text { Kappa }\end{array}$ & $\begin{array}{c}\text { Relevance } \\
\text { Kappa }\end{array}$ \\
\hline 6. $\begin{array}{l}\text { Reprimand bad behavior on } \\
\text { the spot in a loud voice. }\end{array}$ & 0.46 & 0.33 & 0.43 \\
\hline $\begin{array}{l}\text { Send a student home for aggressive } \\
\text { or destructive behavior. }\end{array}$ & 0.56 & 0.34 & 0.28 \\
\hline $\begin{array}{l}\text { Send a student to Principal's } \\
\text { Office for misbehavior. }\end{array}$ & 0.83 & 0.45 & 0.33 \\
\hline $\begin{array}{l}\text { Inform parents about how social } \\
\text { networks work and their correct use. }\end{array}$ & 0.83 & 0.46 & 0.37 \\
\hline
\end{tabular}

Source: Own elaboration.

\section{Teaching and Learning dimension analysis}

In this dimension, there is a moderate agreement, a substantial agreement or an almost perfect agreement among raters in every item, with the exception of items 38 and 39, with a fair agreement among experts, as shown in Table 9. 
Table 9. Lowest Fleiss' Kappa coefficient for the Teaching and Learning dimension

\begin{tabular}{|l|l|c|c|c|}
\hline$\#$ & \multicolumn{1}{|c|}{ Item } & Clarity Kappa & $\begin{array}{c}\text { Coherence } \\
\text { Kappa }\end{array}$ & $\begin{array}{c}\text { Relevance } \\
\text { Kappa }\end{array}$ \\
\hline 38. $\begin{array}{l}\text { Respond to the student's } \\
\text { incorrect answers, validating } \\
\text { student's participation. }\end{array}$ & 0.37 & 1 & 1 \\
\hline $\begin{array}{l}\text { Offer students guidelines and } \\
\text { suggestions to report the group } \\
\text { about their completed work. }\end{array}$ & 0.22 & 0.56 & 0.56 \\
\hline
\end{tabular}

Source: Own elaboration.

\section{Personal dimension analysis}

In the case of the Personal dimension, there is a moderate agreement, a substantial agreement or an almost perfect agreement among raters in almost every item. Table 10 shows that there is just one exception in item 49 , where the agreement level among raters is considered as fair.

Table 10. Lowest Fleiss' Kappa coefficient for the Personal dimension

\begin{tabular}{|l|l|c|c|c|}
\hline \multicolumn{1}{|c|}{ Item } & Clarity Kappa & $\begin{array}{c}\text { Coherence } \\
\text { Kappa }\end{array}$ & $\begin{array}{c}\text { Relevance } \\
\text { Kappa }\end{array}$ \\
\hline $\begin{array}{l}\text { 49. } \begin{array}{l}\text { Notice individual accomplishments } \\
\text { and important events } \\
\text { in students' lives. }\end{array} \\
\text { in }\end{array}$ & 0.36 & 0.56 & 0.56 \\
\hline
\end{tabular}

Source: Own elaboration.

\section{Specific objective 2}

To estimate the CMQ internal consistency using the Cronbach's alpha technique.

\section{Cronbach's alpha applied to the CMQ}

The data collected was computed using the sPSs Statistics program created by IBM. As stated before, a Cronbach's alpha value higher than 0.90 indicates an excellent internal consistency level, while values ranging between 0.90 and 0.80 indicate a good level of internal consistency. The reliability statistics yielded a Cronbach's alpha of 0.904 in the instrument as a whole, which indicates that the questionnaire has an excellent internal consistency, and it is, therefore, highly reliable.

The instrument was also analyzed with the Cronbach's alpha technique separately into its three dimensions: Discipline, Teaching and Learning, and Personal. 
After analyzing the 20 items that formed the Discipline dimension, the results represent what is considered as a good Cronbach coefficient, with a .811 of Cronbach's alpha value.

When the Cronbach's alpha was calculated considering the 20 items forming the Teaching and Learning dimension, the results showed a quite good value, with a .860 value.

After calculating the Cronbach's alpha corresponding to the Personal dimension, we obtained a .884 value that is considered as a good value for the dimension.

Some interesting values were found while performing the item-per-item analysis. According to Gliem and Gliem (2003), the minimum score for an item to be considered correlated with the total test score is between 3.5 and 4. The values below this score have a low level of correlation. According to the results obtained and shown in Table 15, the correlation item-test works well in general terms. However, there is a significant number of items that are below the minimum value of 3.5 (Gliem \& Gliem, 2003), to be considered correlated with the total test score. Items below 3.5 are 4, 6, 7, 8, 9, $12,16,17,19,20,26,32,33,35,36,37,38,41,42,44,52,54$, and 58.

Table 11. Correlation of CMQ's items

\begin{tabular}{|r|c|c|c|c|}
\hline \multicolumn{5}{|c|}{ Item-Total Statistics } \\
\hline Item & $\begin{array}{c}\text { Scale mean if } \\
\text { item deleted }\end{array}$ & $\begin{array}{c}\text { Scale variance } \\
\text { if item deleted }\end{array}$ & $\begin{array}{c}\text { Corrected item- } \\
\text { total correlation }\end{array}$ & $\begin{array}{c}\text { Cronbach's alpha } \\
\text { if item deleted }\end{array}$ \\
\hline 4. & 178.38 & 430.006 & .288 & .903 \\
\hline 6. & 178.92 & 456.954 & -.360 & .911 \\
\hline 7. & 179.46 & 453.058 & -.272 & .910 \\
\hline 8. & 178.38 & 464.726 & -.615 & .912 \\
\hline 9. & 178.15 & 456.535 & -.486 & .909 \\
\hline 12. & 179.50 & 426.100 & .272 & .904 \\
\hline 16. & 178.96 & 422.198 & .318 & .904 \\
\hline 17. & 179.88 & 426.506 & .267 & .904 \\
\hline 19. & 180.50 & 434.100 & .249 & .904 \\
\hline 20. & 179.85 & 431.975 & .198 & .904 \\
\hline 26. & 178.00 & 435.840 & .334 & .903 \\
\hline 32. & 178.19 & 435.842 & .266 & .904 \\
\hline 33. & 178.42 & 439.774 & .040 & .905 \\
\hline 35. & 178.08 & 438.234 & .138 & .904 \\
\hline 36. & 178.35 & 437.355 & .141 & .904 \\
\hline 37 & 177.96 & 440.678 & .051 & .905 \\
\hline
\end{tabular}




\begin{tabular}{|c|c|c|c|c|}
\hline \multicolumn{5}{|c|}{ Item-Total Statistics } \\
\hline Item & $\begin{array}{c}\text { Scale mean if } \\
\text { item deleted }\end{array}$ & $\begin{array}{c}\text { Scale variance } \\
\text { if item deleted }\end{array}$ & $\begin{array}{c}\text { Corrected item- } \\
\text { total correlation }\end{array}$ & $\begin{array}{c}\text { Cronbach's alpha } \\
\text { if item deleted }\end{array}$ \\
\hline 38. & 178.23 & 432.505 & .294 & .903 \\
\hline 41. & 178.54 & 431.458 & .275 & .903 \\
\hline 42. & 177.96 & 436.198 & .268 & .904 \\
\hline 44. & 177.88 & 436.346 & .311 & .903 \\
\hline 52. & 177.85 & 440.775 & .096 & .904 \\
\hline 54. & 178.23 & 432.185 & .305 & .903 \\
\hline 58. & 178.00 & 435.440 & .289 & .903 \\
\hline
\end{tabular}

\section{Source: Own elaboration.}

It is worth noting that the last column of Table 15 shows the Cronbach's alpha value if the low-value items are deleted. Only removing items 6, $7,8,9,33$, and 37, the alpha coefficient would increase significantly. Such is the case of item 8 , which, if deleted, the Cronbach's alpha would increase to 0.912 . As seen, only removing 6 out of 60 items, the alpha coefficient would increase at some degree. Nonetheless, that does not mean that these items should be deleted. One of the factors that may have influenced these figures is the fact that research participants were mainly novice teachers with beginning teaching experience. This is evidenced especially in classroom management techniques that have to do with the Discipline dimension, where the lower ranges are obtained.

\section{Conclusions}

The purpose of this study was to approach the validation of a questionnaire to identify classroom management techniques used by pre- and in-service teachers of English. The Delphi and Fleiss' Kappa techniques were used to approach the validation of the CMQ. The Cronbach's alpha technique was used to comply with the estimation of the CMQ reliability through its internal consistency coefficient.

Once the two member-checking techniques, Delphi and Fleiss' Kappa, were applied, and after a review board of 12 expert raters evaluated the questionnaire, it was concluded that almost every item of the questionnaire was considered appropriate by the raters in terms of clarity, coherence and relevance, with the exception of items 15, 16, 20, and 39, with only 4 out of 60 items. Consequently, such items were properly rewritten and/or relocated. Once the Fleiss' Kappa technique was applied, it was concluded that there was either a moderate agreement, a substantial agreement or an almost perfect agreement between raters, with the exception of items 
$6,15,16$, and 20 referring to the Discipline dimension; items 38 and 39 belonging to the Teaching and Learning dimension, and item 49 from the Personal dimension. In total, 7 out of 60 items in which raters reached a fair agreement regarding the clarity, coherence and relevance of such items. After applying these two member-checking techniques, the conclusion is that this research objective was achieved. The item modifications suggested were made, and a revised version of the Classroom Management Questionnaire was obtained.

The other research objective was to estimate the CMQ internal consistency using the Cronbach's alpha technique, which was applied after the questionnaire was answered by 31 English teachers and teachers to-be who participated in the study. Once Cronbach's alpha results were obtained, it was concluded that, overall, the questionnaire had an excellent internal consistency and it was, therefore, highly reliable. The item-per-item analysis revealed that a significant number of items did not have a good level of correlation from the total score. However, that does not mean that those items should be deleted. Only removing items 6, 7, 8, 9, 33 and 37, that is, 6 out of 60 , the alpha coefficient would increase at some degree. One of the factors that influenced these figures was the fact that research participants were mainly novice teachers with little teaching experience, especially using classroom management techniques that have to do with the Discipline dimension.

\section{References}

Awad, A. (2016). The challenge of classroom leadership and management facing newly appointed teachers. American Journal of Educational Research, 4(2A), 25-29.

George, D., \& Mallery, P. (2003). spss for Windows step by step: A simple guide and reference, 11.0 update ( $4^{\text {th }}$ Ed.). Boston, MA: Allyn \& Bacon.

Gliem, J., \& Gliem, R. (2003). Calculating, interpreting and reporting Cronbach's alpha reliability coefficient for Likert-type scales. Proceedings of the Midwest Research to Practice Conference in Adult, Continuing, and Community Education, 82-88. Retrieved from https://scholarworks.iupui.edu/bitstream/handle/1805/344/Gliem+\&+Gliem.pd$\mathrm{f}$ ? sequence $=1$

Gordon, D. (2001). Classroom management problems and solutions. Music Educators Journal, 88(2), 17-23. Retrieved from http://dx.doi. org/10.2307/3399737

Hoy, W. (2001). The pupil control studies. A historical, theoretical and empirical analysis. Journal of Educational Admin, 39(5), 424-441. 
Hsu, C.-C., \& Sandford, B. A. (2007). The Delphi technique: Making sense of consensus. Practical Assessment Research \& Evaluation, 12(10), 1-8. Retrieved from http://pareonline.net/getvn.asp? $v=12 \& n=10$

Landis J., \& Koch, G. (1977). The measurement of observer agreement for categorical data. Biometrics, 33(1), 159-174.

Martin, N., \& Baldwin, B. (1993, November). An examination of the construct validity of the inventory of classroom management style. Paper presented at the Annual Conference of the Mid-South Educational Research Association, New Orleans, LA, United States.

Martin, N., Schafer, N., McClowry, S., Emmer, E., Brekelmans, M., Mainhard, T., \& Wubbel, T. (2016). Expanding the definition of classroom management: Recurring themes and conceptualizations. Journal of Classroom Interaction, 51, 31-41.

Marzano, R. (2003). What works in schools. Alexandria, VA: Association for Supervision \& Curriculum Development.

Marzano, R., Marzano, J., \& Pickering, D. (2003). Classroom management that works. Alexandria, VA: Association for Supervision and Curriculum Development.

Marzano, R., Foseid, M., Foseid, M., Gaddy, B., \& Marzano, J. (2005). A handbook for classroom management that works. Alexandria, VA: Association for Supervision and Curriculum Development.

Nault, T. (1994). L'enseignant et la gestion de la classe. Comment se donner la liberté d'enseigner [The teacher and classroom management. How to give freedom to teach] Montréal: Logiques.

Okutan, M. (2005). Sınıf yönetiminde örnek olaylar [Case studies of classroom management]. MilliEğitim, 33 (168). Retrieved from http:// dhgm.meb.gov.tr/yayimlar/dergiler/Milli_Egitim_Dergisi/168/index3-okutan.htm

Özcan, M. (2017). Effective classroom management strategies for educational practice. In S. Scatolini, G. Milton, \& Y. Hanouna (Eds.), Inclusiveness because we can: Aspects of discourses and praxes of inclusion, with a focus on education (pp. 107-117). Oman: Euro-Khaleeji Research and Publishing House.

Pearson Education Canada Inc. (2005). Beliefs about discipline inventory. In C. H. Wolfgang (Ed.), Solving Discipline Problems: Methods and Models for Today's Teachers (pp. 9-11). New York City, NY: John Wiley \& Sons.

Scrivener, J. (2012). Classroom management techniques. Cambridge, UK: Cambridge University Press.

Tavakol, M., \& Dennick, R. (2011). Making sense of Cronbach's alpha. International Journal of Medical Education, 2, 53-55. http://dx.doi. org/10.5116/ijme.4dfb.8dfd 
Webster-Stratton, C. (2012). The incredible years. Training series for parents, teachers, and children. Retrieved from http://www.incredibleyears.com

Willower, D., Eidell, T., \& Hoy, W. (1967). The school and pupil control. University Park, PA: The Pennsylvania State University.

Wolfgang, C., \& Glickman, C. (1986). Solving discipline problems. Boston, MA: Allyn and Bacon. 


\section{Annex}

\section{Inventory of Classroom Management Techniques}

Dear Teacher,

The purpose of this questionnaire is to examine classroom management practices in three different dimensions: Discipline, Teaching and Learning, and Person. Your responses will be treated with the utmost confidence and will be used only for academic research purposes. This inventory is anonymous and your participation is voluntary. We appreciate your willingness to contribute in our research study.

Personal Information

Please, tick the corresponding answer(s).

Age Range:
a) $21-25$
b) $26-30$
c) $31-35$
d) $36-40$
e) $41-50$
f) $51-60$
g) $61-70$

Sex:
a) Male
b) Female

School levels you regularly teach:
a) Nursery Education
b) Primary Education
c) Secondary Education
d) Tertiary Education

The type of school you currently work in:
a) Public
b) Semi - Private
C) Private

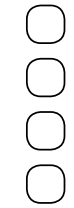

Years of teaching experience (from Professional Practicum onwards) 


\section{Instructions:}

We would like to know how often you use the following techniques for managing your classroom. Circle the option that best applies to you, taking into account that:

$$
\mathbf{R}=\text { Rarely } \quad \mathbf{S}=\text { Sometimes } \quad \mathbf{O}=\text { Often } \quad \mathbf{U}=\text { Usually }
$$

Rarely: The technique is displayed almost never

Sometimes: The technique is displayed occasionally

Often: The technique is displayed regularly

Usually: The technique is displayed almost always

When dealing with discipline...

\begin{tabular}{|c|c|c|c|c|c|}
\hline \multicolumn{6}{|c|}{ Discipline Dimension } \\
\hline Item & Inside the classroom & $\mathbf{R}$ & $\mathbf{s}$ & 0 & u \\
\hline & I involve students in establishing rules and procedures. & $\mathrm{R}$ & $\mathrm{S}$ & O & $u$ \\
\hline & $\begin{array}{l}\text { I share with students the reasons behind } \\
\text { the disciplinary approach(es) I use. }\end{array}$ & R & S & $\mathrm{O}$ & U \\
\hline & $\begin{array}{l}\text { I provide positive reinforcement to students } \\
\text { for appropriate behavior (e.g. special helper, } \\
\text { extra computer time, tangible rewards) }\end{array}$ & R & S & O & $U$ \\
\hline & $\begin{array}{l}\text { I make students aware of consequences } \\
\text { for misbehavior (e.g. loss of break } \\
\text { time, extra classroom time). }\end{array}$ & $\mathrm{R}$ & S & $\mathrm{O}$ & $U$ \\
\hline & $\begin{array}{l}\text { I use class time to reflect on appropriate } \\
\text { behavior with students as a group. }\end{array}$ & R & S & O & $U$ \\
\hline & $\begin{array}{l}\text { I redirect inappropriate behavior on } \\
\text { the spot, using loud voice. }\end{array}$ & $\mathrm{R}$ & S & $\mathrm{O}$ & U \\
\hline & I ignore misbehavior that is non-disruptive to class. & $\mathrm{R}$ & $\mathrm{S}$ & O & U \\
\hline & $\begin{array}{l}\text { I use short verbal cues to stop misbehavior (e.g. } \\
\text { say student's name aloud, use "shh" sound). }\end{array}$ & R & S & $\mathrm{O}$ & U \\
\hline & $\begin{array}{l}\text { I use nonverbal signals to stop misbehavior (e.g. make } \\
\text { eye contact, approach and touch disruptive students). }\end{array}$ & $R$ & S & O & U \\
\hline & $\begin{array}{l}\text { I use self-assessment forms for students to } \\
\text { evaluate their own behavior (e.g. checklists). }\end{array}$ & $\mathrm{R}$ & S & $\mathrm{O}$ & $U$ \\
\hline & I inform parents about classroom expectations. & $\mathrm{R}$ & $\mathrm{S}$ & $\mathrm{O}$ & U \\
\hline & I send for parents to report inappropriate behavior. & $R$ & 5 & O & U \\
\hline & I send for parents to report good behavior. & $\mathrm{R}$ & $\mathrm{s}$ & $\mathrm{O}$ & $\mathrm{u}$ \\
\hline
\end{tabular}




\begin{tabular}{|l|l|c|c|c|c|}
\hline \multicolumn{5}{|l|}{ Discipline Dimension } \\
\hline Item & \multicolumn{1}{|c|}{ Inside the classroom } & R & S & O & U \\
\hline & $\begin{array}{l}\text { I collaborate with parents on a home- } \\
\text { school behavior plan. }\end{array}$ & R & S & O & $U$ \\
\hline $\begin{array}{l}\text { I teach parents activities to do with students at } \\
\text { home to reinforce good behavior at school. }\end{array}$ & R & S & O & $U$ \\
\hline $\begin{array}{l}\text { I inform parents about the policies regarding } \\
\text { the use of mobile phones at school. }\end{array}$ & R & S & O & $U$ \\
\hline $\begin{array}{l}\text { I inform parents about social networks and their } \\
\text { correct use (e.g. "Facebook", "Twitter","Instagram"). }\end{array}$ & R & S & O & $U$ \\
\hline $\begin{array}{l}\text { I send home Teacher-to-Parent Communication } \\
\text { Ilters or newsletters regarding positive and } \\
\text { negative aspects of their children's behavior. }\end{array}$ & R & S & O & $U$ \\
\hline $\begin{array}{l}\text { I send students home for aggressive } \\
\text { or disruptive behavior. }\end{array}$ & R & S & O & $U$ \\
\hline I send students to the Principal's office for misbehavior. & R & S & O & $U$ \\
\hline
\end{tabular}

When dealing with Teaching and Learning...

\begin{tabular}{|c|c|c|c|c|c|}
\hline \multicolumn{6}{|c|}{ Teaching and Learning Dimension } \\
\hline Item & Organization of the lesson & $\mathbf{R}$ & $\mathbf{S}$ & O & U \\
\hline & $\begin{array}{l}\text { I take into account different learning } \\
\text { styles when preparing the lesson. }\end{array}$ & $R$ & $\mathrm{~S}$ & O & $U$ \\
\hline & $\begin{array}{l}\text { I take into account students' previous knowledge } \\
\text { to plan the activities based on their level. }\end{array}$ & $\mathrm{R}$ & $\mathrm{S}$ & O & $U$ \\
\hline & I establish routines for group work when needed. & $\mathrm{R}$ & $\mathrm{S}$ & $\mathrm{O}$ & $\cup$ \\
\hline & $\begin{array}{l}\text { I start the lesson by giving students an } \\
\text { opportunity to set their own learning goals. }\end{array}$ & $\mathrm{R}$ & $\mathrm{S}$ & O & $\cup$ \\
\hline & $\begin{array}{l}\text { I make sure that the learning goals are clearly stated } \\
\text { for students to understand them (e.g. displaying } \\
\text { them on the board, saying them out loud). }\end{array}$ & $R$ & $\mathrm{~S}$ & $\mathrm{O}$ & $\cup$ \\
\hline & $\begin{array}{l}\text { I organize the activities into logical stages } \\
\text { to fulfill the objectives of the lesson. }\end{array}$ & R & $\mathrm{S}$ & $\mathrm{O}$ & $\cup$ \\
\hline & $\begin{array}{l}\text { I use different types of seating } \\
\text { arrangements depending on the type of } \\
\text { activity students are assigned to do. }\end{array}$ & $R$ & $\mathrm{~S}$ & $\mathrm{O}$ & $\cup$ \\
\hline & $\begin{array}{l}\text { I prepare students for transitions and interactions } \\
\text { (e.g. bathroom rules, moving from one classroom } \\
\text { to another) using predictable routines. }\end{array}$ & R & $\mathrm{S}$ & 0 & $\cup$ \\
\hline & $\begin{array}{l}\text { I create extra activities for students to work } \\
\text { when they have completed their main task. }\end{array}$ & $R$ & $\mathrm{~S}$ & 0 & $\cup$ \\
\hline & $\begin{array}{l}\text { I assign advanced students as assistants to help } \\
\text { weaker learners in the completion of their tasks. }\end{array}$ & $\mathrm{R}$ & $\mathrm{S}$ & 0 & $\cup$ \\
\hline
\end{tabular}




\begin{tabular}{|c|c|c|c|c|c|}
\hline Item & Interaction during the lesson & $\mathbf{R}$ & s & 0 & $u$ \\
\hline & $\begin{array}{l}\text { I start the lesson in an unusual manner to catch } \\
\text { students' attention (e.g. telling an amusing story or } \\
\text { personal anecdote; starting in a very quiet or low voice). }\end{array}$ & $\mathrm{R}$ & s & O & $u$ \\
\hline & $\begin{array}{l}\text { I model the task to demonstrate what students are } \\
\text { expected to do (e.g. role playing the task with a student, } \\
\text { assigning a student to demonstrate the task). }\end{array}$ & $\mathrm{R}$ & s & O & $\cup$ \\
\hline & $\begin{array}{l}\text { I use concept check questions to make sure } \\
\text { instructions are understood (e.g. "what do you have to } \\
\text { do first?", "do you have to work in pairs or in groups?"). }\end{array}$ & $\mathrm{R}$ & s & $\mathrm{O}$ & $U$ \\
\hline & $\begin{array}{l}\text { I use body language to make } \\
\text { instructions understandable. }\end{array}$ & $\mathrm{R}$ & s & $\mathrm{O}$ & $u$ \\
\hline & $\begin{array}{l}\text { I Reep English simple and clear (e.g. trying to } \\
\text { pronounce every word well, using appropriate } \\
\text { pacing according to students' English level). }\end{array}$ & $\mathrm{R}$ & $\mathrm{S}$ & $\mathrm{O}$ & $u$ \\
\hline & $\begin{array}{l}\text { I monitor students' work spending equal amount } \\
\text { of time in all quadrants of the classroom. }\end{array}$ & $R$ & $S$ & O & $U$ \\
\hline & $\begin{array}{l}\text { I respond to students' answers using verbal } \\
\text { praising (e.g. "Brilliant!", "Great!", "Nice job!"). }\end{array}$ & $\mathrm{R}$ & $\mathrm{S}$ & $\mathrm{O}$ & $u$ \\
\hline & $\begin{array}{l}\text { I respond to students' incorrect answers } \\
\text { validating students' participation (e.g. } \\
\text { "that's partly correct", "good effort"). }\end{array}$ & $\mathrm{R}$ & $\mathrm{S}$ & $\mathrm{O}$ & U \\
\hline & $\begin{array}{l}\text { I give students instructions on how to } \\
\text { report their completed work. }\end{array}$ & $\mathrm{R}$ & $S$ & $\mathrm{O}$ & $U$ \\
\hline & $\begin{array}{l}\text { I finish the class with a reflection activity } \\
\text { about the lesson (e.g. written reflection, oral } \\
\text { reflection, report on what was learnt). }\end{array}$ & $\mathrm{R}$ & $\mathrm{S}$ & $\mathrm{O}$ & $U$ \\
\hline
\end{tabular}

When dealing with the student as a Person...

\begin{tabular}{|c|l|c|c|c|c|}
\hline \multicolumn{5}{|c|}{ Personal Dimension } \\
\hline Item & \multicolumn{1}{|c|}{ Teacher-student personal communication } & R & S & O & U \\
\hline & $\begin{array}{l}\text { I attempt to be "Me" rather than "the Teacher" } \\
\text { to make students feel I am approachable. }\end{array}$ & R & S & O & U \\
\hline & I learn students' names to recognize them as individuals. & R & S & O & U \\
\hline & I interact with students as individuals. & R & S & O & U \\
\hline & $\begin{array}{l}\text { I use eye contact to make students feel } \\
\text { I care about what they say and do. }\end{array}$ & R & S & O & U \\
\hline $\begin{array}{l}\text { I learn about the different types of students' } \\
\text { personal and social needs (e.g. using 'getting to } \\
\text { know each other activities', questionnaires). }\end{array}$ & R & S & O & U \\
\hline & I incorporate students' personal interests into teaching. & R & S & O & $U$ \\
\hline & I encourage creativity and self-expression in students. & R & S & O & $U$ \\
\hline & $\begin{array}{l}\text { I talk with students' previous teachers to } \\
\text { gather information about students. }\end{array}$ & R & S & O & $U$ \\
\hline $\begin{array}{l}\text { I praise individual accomplishments and } \\
\text { important events in students' lives. }\end{array}$ & R & S & O & $U$ \\
\hline $\begin{array}{l}\text { I talk with a student after an emotional outburst to } \\
\text { demonstrate I am personally interested in him/her. }\end{array}$ & R & S & O & $U$ \\
\hline
\end{tabular}




\begin{tabular}{|c|c|c|c|c|c|}
\hline Item & Psychological and social classroom environment & $\mathbf{R}$ & $\mathbf{S}$ & 0 & $\mathrm{U}$ \\
\hline & $\begin{array}{l}\text { I begin the lesson with activities to reinforce a } \\
\text { sense of collaboration among students. }\end{array}$ & $\mathrm{R}$ & S & ○ & $\cup$ \\
\hline & I encourage students to be respectful one another. & $\mathrm{R}$ & $\mathrm{S}$ & $\mathrm{O}$ & $U$ \\
\hline & $\begin{array}{l}\text { I promote positive social values (e.g. } \\
\text { helping, sharing, being patient). }\end{array}$ & $\mathrm{R}$ & $\mathrm{S}$ & O & $\cup$ \\
\hline & $\begin{array}{l}\text { I encourage students to reach an agreement } \\
\text { through conversations to resolve any issue. }\end{array}$ & R & $\mathrm{S}$ & O & $\cup$ \\
\hline & $\begin{array}{l}\text { I teach students to work together } \\
\text { cooperatively toward academic goals. }\end{array}$ & R & S & O & $\cup$ \\
\hline & $\begin{array}{l}\text { I use problem solving scenarios with students } \\
\text { to develop their problem solving skills. }\end{array}$ & $\mathrm{R}$ & $\mathrm{S}$ & O & $\cup$ \\
\hline & $\begin{array}{l}\text { I promote students' responsibility } \\
\text { in my classroom practice. }\end{array}$ & $\mathrm{R}$ & $\mathrm{S}$ & $\bigcirc$ & $\cup$ \\
\hline & I promote respect for cultural diversity in the classroom. & $\mathrm{R}$ & $\mathrm{S}$ & $\mathrm{O}$ & $U$ \\
\hline & I help students to become aware of their own thinking. & $\mathrm{R}$ & $\mathrm{S}$ & $\mathrm{O}$ & 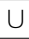 \\
\hline & $\begin{array}{l}\text { I help students to develop their ability to } \\
\text { make decisions by themselves. }\end{array}$ & R & S & $\mathrm{O}$ & $\cup$ \\
\hline
\end{tabular}


